\title{
Multilateral development banks, new developmentalism and local currency financing
}

\author{
Bancos multilaterais de desenvolvimento, novo \\ desenvolvimentismo e financiamento em moeda local
}

LUIZ CARLOS BRESSER-PEREIRA* CINTHIA BECHELAINE**

\begin{abstract}
RESUMO: Os bancos multilaterais de desenvolvimento (MDBs) são projetados para financiar investimentos que promovam o desenvolvimento econômico e social global. O objetivo deste artigo é discutir um componente-chave para atender à demanda por investimentos em países em desenvolvimento, ou seja, a capacidade dos bancos multilaterais de fornecer empréstimos em moeda local e não em moeda estrangeira. Para explicar como essas instituições cumprem esse propósito, distinguimos os MDBs "tradicionais" dos "novos", discutimos os problemas gerados pelo endividamento em moeda estrangeira e exploramos uma saída ou uma explicação alternativa, baseada na teoria do Novo Desenvolvimentismo e no desafio da comunidade local quanto a financiamento de moeda.

PALAVRAS-CHAVE: Bancos multilaterais de desenvolvimento; novo desenvolvimentismo; financiamento; políticas de moeda.
\end{abstract}

ABSTRACT: Multilateral Development Banks (MDBs) are designed to finance investments that promote global economic and social development. The objective of this paper is to discuss a key component in meeting the demand for investment in developing countries, namely the ability of MDBs to provide loans in local rather than foreign currency. To explain how these institutions fulfill this purpose, we distinguish "traditional” from "new" MDBs, discuss the problems generated from foreign currency indebtedness, and explore a way out, or an alternative explanation, based on New Developmentalism theory and the challenge of local currency financing.

KEYWORDS: Multilateral development banks; new developmentalism; financing; currency policies.

JEL Classification: F3; F4; G2; O2.

\footnotetext{
* Professor emérito da Fundação Getúlio Vargas, São Paulo/SP, Brasil. E-mail: bresserpereira@gmail. com; http://orcid.org/0000-0001-8679-0557.

* Doutoranda de Administração Pública e Governo, Escola de Administração de Empresas de São Paulo - Fundação Getúlio Vargas - EAESP-FGV, São Paulo, SP, Brasil. E-mail: Cinthia.bechelaine@gmail. com. Orcid https://orcid.org/0000-0002-5036-9012. Submitted: 10/August/2018; Approved: 19/October/2018.
} 


\section{INTRODUCTION}

More than seventy years after the creation of the first multilateral development institution during the iconic Bretton Woods Conference, the role and behavior of Multilateral Development Banks (MDBs) have inspired multiple reassessments. Interpretations of how the MDBs should finance investments to promote development have been revised according to differing definitions of economic development and the conjuncture of each period and region. One point on which MDB policies have hewn toward the traditional, however, concerns the approach of foreign currency-based financing in the public sector of developing countries.

Since their inception, MDBs have conventionally provided financing to developing countries in foreign currencies, which have caused serious problems such as currency mismatches. The current account deficits and increased external debt caused by the external savings crisis in Latin American countries from 1980 on raises serious questions about this "traditional" mode of financing. This dysfunction of debts in foreign currency, although rarely discussed by economists (Bresser-Pereira, 2017a), is approached by the new developmentalist theory, which demonstrates how growth policy based on external savings, if not carefully evaluated and monitored, can become more of an obstacle than an aid to developing countries.

This issue was addressed at the Shanghai Forum, on May 2018, by Bresser-Pereira in the paper and round table entitled Why multilateral development banks should provide finance in domestic currencies: a growth and financial stability proposal. On this occasion, two sides of the question were discussed: on one hand, the relevance of multilateral institutions in promoting growth in developing countries and, on the other hand, the risk of external indebtedness, given that loans are granted for the most part in reserve currency. Bresser-Pereira (2018) explains that the policy of growth with foreign debt could become self-destructive as deficit financing leads to the appreciation of the national currency, which, in turn, encourages consumption rather than investment. In this sense, multilateral banks play an important role in promoting new forms of financing in local currency, whether for major infrastructure, innovation or renewable energy projects.

The objective of this paper is to discuss, from a theoretical perspective, a key component to provide greater flexibility in meeting the investment demand of developing countries, particularly the capacity of MDBs to provide loans in local rather than foreign currency. The new theory of developmentalism is offered as a "way out" for the serious dysfunctions generated by external indebtedness and a new set of explanations for this persistent yet so little discussed problem.

This paper thus proposes a starting point, identifies a problem, points to a way out and poses a challenge. The starting point is the discussion of the role of MDBs in development financing, dividing them between "traditional" and "new" banks. The problem is foreign debt in foreign currency itself and its consequences. The way out, or explanation of the problem, lies in new developmentalism. And, finally, the challenge: the pioneering local-currency financing practices encouraged by the new 
MDBs - in particular the Asian Infrastructure Investment Bank (AIIB) and New Development Bank (NDB), institutions founded since 2014.

To briefly assess the history of multilateral development finance, it is important to understand the waves of transformation undergone by MDBs, as follows in the next section.

\section{THE STARTING POINT: MULTILATERAL DEVELOPMENT BANKS (MDBS)}

As the name suggests, MDBs are at the center of the system of financing investments that promote global economic and social development (Shelepov, 2017). The interpretation of this broad mandate, however, has changed significantly over time, through identity crises and with increasing distance from the original developmentalist ideas and policies that guided the creation of the International Bank for Reconstruction and Development (IBRD) (Bresser-Pereira, 1995). According to Wang (2017), from the appearance of the first institutions until the establishment of the most recent multilateral banks - such as the AIIB and NDB - these institutions underwent three waves of transformation, which, according to Shelepov (2017), allows us to categorize them as either "new" or "traditional" development banks.

The first wave of creation of development institutions came at the end of World War II, with the founding of the International Monetary Fund (IMF) and IBRD, which sought to provide investment capital for rebuilding war-torn economies. Following the successful reconstruction of Europe, the demands for income equality and modernization of productive structures, with their great attendant need for investment, led the MDBs to finance infrastructure and industrialization projects in developing countries. And with this mission, from late 1940s to the mid-1960s, other multilateral development banks were created in addition to IBRD: the Inter-American Development Bank (IDB), the African Development Bank (ADB), the Asian Development Bank (ADB), the Development Bank of Latin America (CAF) and the Islamic Development Bank (ISDB).

For Bresser-Pereira (1995: 7), the original idea of creating the World Bank and other multilateral institutions was based on developmentalist ideologies, whose fundamental strategy was "external financing for infrastructure investments and the protection of nascent industry." From this perspective, external financing was based on the "big push" argument; in other words, the need for an increase in the initial investment, usually with the support of international capital, to raise the capacity for industrialization of developing countries. In addition to the "initial push," the protection of nascent industry and import substitution also garnered support from multilateral institutions.

However, World Bank strategies to intervene in less developed regions underwent constant change. Birdsall and Londono (1997) argue that, in the 1970s, although the World Bank adopted the objective of poverty reduction, this strategy was more evident in the Bank's rhetoric than in its financing decisions. Bresser-Pereira (1995) 
points out that, from this time on, there were indications of a crisis in developmentalist theory, and multilateral institutions changed their behavior to a significant extent. The World Bank, which was the leading model for developmental economists, became an important instrument of Washington Consensus practices. Developing countries were advised to open, deregulate and privatize their economies, while the IMF provided "structural adjustment" loans with external savings.

Starting in the 1990s, the second wave of MDBs, including the creation of the European Bank for Reconstruction and Development (EBRD) - founded in 1991 - arose in a different context (Wang, 2017). In political terms, it succeeded the collapse of communist regimes in Central and Eastern Europe and, ideologically, the developmental paradigm - the reason for the original creation of the MDBs was perceived as a failed project. In this wave, the idea behind the EBRD was to help develop market-oriented economies (Wang, 2017), directly influenced by neoliberal directives and the ideology of market fundamentalism that would delegitimize the developmental and structuralist perspectives. The focus during this period was on the promotion of market-oriented economies and investment in private sector projects, especially in post-communist countries in Central and Eastern Europe and the former Soviet Union (Wang, 2017).

The creation of the new multilateral banks, such as NDB and AIIB, since 2014, is part of the third and most recent wave of MDBs, emerging as alternatives to "traditional" banks. According to Wang (2017), the banks of the third wave were born amidst the recent development of international capital markets and a shift in power within the global system: namely, from industrialized countries to emerging economies. Roberts et al. (2017) explains that the BRICS countries (Brazil, Russia, India, China and South Africa) recognize an ongoing global power shift that challenge the West's pretensions to permanent stewardship of the existing economic order. Wang (2017) adds that, since 2000, the BRICS' share of the global GDP grew from $8 \%$ to $22 \%$, proving that, together, these countries may be able to exert more influence on international monetary policy.

Thus, unlike most traditional MDBs, the new third wave multilateral banks such as NDB and AIIB are being led by developing countries, with China playing a particularly prominent role. According to Shelepov (2017), the creation of the new banks is intended to address the persistent need for infrastructure investment, essential for developing countries to realize their growth potential and influence on the global economy.

It is possible to observe from the three waves of multilateral development banks - developmentalist, neoliberal and more recently, tracking the shifts in power in the international system (Wang, 2017), that the conjuncture of the period and the predominant ideology motivated multiple reassessments of the roles of the MDBs. With the constant changes in their roles, it bears underscoring the importance of MDBs in raising international capital to support sovereign governments in developing countries and to make long-term investments in social and infrastructure projects (Wang, 2017).

Returning to the objective of this study, which assesses the risks of foreign 
currency financing in the public sector, we note that regardless of the type of financing - whether for industrialization or infrastructure - financing in foreign currency still predominates. The problems that arise from this type of financing deserve more discussion.

\section{THE PROBLEM: FOREIGN CURRENCY FINANCING}

Despite the indisputable importance of long-term credit for development finance, the question that remains is: is foreign currency financing the best way to promote development?

Bresser-Pereira, in his article "Why the Rest do not need foreign finance" (2017a), discusses how underdeveloped nations failed to question the prevailing understanding that foreign currency financing is the only path to economic growth. The author suggests that a certain consensus exists, ruled by economic liberalism and still little criticized by economists, in favor of growth policy through foreign debt. In other words, developing countries learn that they should increase their savings and investment capacity and that the best way to do so is through foreign financing. However, what has been observed since the XIX century is that developing countries that resorted to multilateral banks and foreign currency contracts with such institutions experienced repeated and severe monetary crises. It is now understood that these crises are caused by account deficits and falling commodity prices and, more importantly, by the need to secure additional capital inflows to finance current account deficits (the so-called "foreign savings") caused by the appreciation of the national currency in the long term and the consequent loss of competitiveness of domestic businesses.

Frieden (2014) discusses the crucial importance of decisions about exchange rates in developing countries resulting from government currency exchange policies. Perry (2009) indicates that developing countries are more prone to monetary and financial crises due to greater macroeconomic volatility. According to the author, high volatility and propensity for financial and currency crises are recurrent characteristics of developing countries. The author also argues that these crises seem to be serious impediments to development, as they are closely associated with instability of consumption, low long-term growth and high levels of inequality and poverty.

According to Hoschka (2005), foreign currency loans may generate currency risks if the country's or company's revenues are in local currency. For example, the author cites the mismatch between liabilities and assets of an Indian electric power plant that is financed in dollars but receives electricity tariffs in rupees. In this case, revenues remain unchanged if the rupee depreciates against the dollar, but, nevertheless, the financial obligations of the borrower are higher. Consequently, given the uncertainties inherent in the exchange rate and the lack of government risk allocation, exchange rate risk is a significant issue that must be considered in long-term loans between multilateral institutions and developing countries (Bresser-Pereira and Nakano, 2003). 
One of the main challenges in financing projects in developing countries is determining who should take on the exchange risk (Hoschka, 2005). The creditors, in addition to pricing interest rates and tariffs into higher interest payments on the principal, expect the borrowing country to bear all foreign exchange risk. Developing countries, on the other hand, generally have underdeveloped long-term domestic currency markets and insufficient access to currency risk management tools that would help them cope with adverse exogenous shocks (Perry, 2009). According to Perry (2009), such limitation can be attributed in part to domestic factors - weak technical capabililties, political and institutional problems - but also to market failures associated with cost, liquidity and coordination of externalities.

In addition to the technical complexity of exchange rate risk, another important issue raised by Bresser-Pereira and Gala (2008) is the lack of assurance that foreign currency loans will be allocated directly to investment projects. On the contrary, in many cases these foreign currency loans tend to finance consumer markets. The authors demonstrate that foreign savings in foreign currency lead to an account deficit which, when financed with capital inflows higher than those needed to clear the current account, raise the exchange rate and reduce the rate of industrial profit. The increasing inflow of foreign capital, which is necessary to finance deficits, artificially increases the purchasing power of rentier capitalists' wages and incomes (dividends, interest, and rent). In the intervening time, the expected profit rate of industrial businesses drops, consumption increases more rapidly than the investment and country's foreign debt increases, leading to a cyclical balance-of-payments crisis.

As demonstrated by Bresser-Pereira and Nakano (2003), the dependent growth strategy, based on the growth of foreign savings since 1980, was accepted as "true" by several countries in Latin America and became a widespread belief among economists, politicians and businessmen. In the decade that followed, the consequences of this model emerged, such as the substitution of domestic for external savings, increase in consumption, high external debt and, therefore, a financial crisis in these countries, including Brazil. Fiscal adjustment was undertaken seriously and the reforms set forth in the Washington Consensus, particularly privatization and market liberalization, advanced everywhere, with the support of multilateral organizations.

Thus, it is evident that, although foreign investment can help developing countries to grow, they can also increase financial vulnerability as industrial businesses or, more precisely, businesses producing internationally tradable goods and services become less competitive and more exposed to exchange rate risks and capital outflows.

\section{THE WAY OUT: NEW DEVELOPMENTALISM}

New Developmentalism theory, framed by a group of Brazilian economists associated with Luiz Carlos Bresser-Pereira, emerges as a "third way" between previous developmental discourses and neoliberalism (Bresser-Pereira, 2006, 2007, 2016). The term "new" is relevant insofar as it differs from the "old" and outdated 
import substitution theory (Bresser-Pereira, 2006). The difference between neoliberal orthodoxy and new development lies in its theoretical basis, which considers the state an essential element in the development process, unlike neoliberal theory, which sees the market as responsible for development. Unlike other theories, new developmentalism pays particular attention to the exchange rate in developing countries, which tends to appreciate in the long-run and consequently makes industrial investment impracticable. Therefore, new developmentalism is a set of political, institutional and economic guidelines for developing countries such as Brazil to achieve per capita income levels, growth rates, and stability that approximate those of developed countries.

It is worth nothing that the foundations of new developmentalism theory consider essential the role of the state, which, according to the conjuncture, must regulate and intervene in the economy to guarantee general conditions of capital accumulation and increase in productivity (Bresser-Pereira, Oreiro and Marconi, 2016). As Prebisch (1962) already pointed out, the State's participation is a fundamental issue for the implementation of a national developmental strategy, which will not occur spontaneously, as holds the neoliberal logic. Reinert (2007) reiterates this view, in which development must be the result of conscious and intentional policies - in other words, as a consequence of coordinated and state-supported actions.

This argument also highlights the role of the state in the catching-up process, particularly in arranging combined efforts to reduce the technological gap between developed and developing countries. The concept of catching-up considers that is possible for technologically deficient countries to grow at higher rates than those on the cutting edge by applying knowledge already established by developed countries and by seeking changes in their productive structure (Bresser-Pereira, 2017b). Reinert (2007) indicates how high value-added activities counteract low value-added activities, generally carried out in developing countries with low technological innovation, and the importance of increasing productivity and sophistication. For new developmentalism, it is essential to encourage innovation and the creation of high value-added technological companies (Bresser-Pereira, 2017).

Therefore, new developmentalism theory incorporates three spheres of thought (Bresser-Pereira, 2016): first, political economy, emphasizing the role of the state; second, microeconomics, based on concepts of structural change, of classic developmentalism and of productive sophistication, with the transfer of labor to more productive sectors, with higher value added per capita; and, finally, macroeconomics, playing an essential role in discussions of foreign debt. In its macroeconomic component, new developmentalism focuses mainly on exchange rates and account balances, offering a "way out" for the problem set forth in this paper.

The macroeconomic component of new developmentalism theory highlights the importance of maintaining macroeconomic prices (inflation rate, interest rate, exchange rate, wage rate and profit rate) at the correct levels for the catching-up process to occur based on the growth of the productive structure - that is, for a structural change towards greater participation in manufacturing and high value-added services (Marconi and Brancher, 2017). Therefore, in addition to ensuring 
public order, public education, promotion of science and technology, and investments in infrastructure, the state must also ensure that macroeconomic prices are at the correct levels, specifically at levels that allow the production of high value-added goods to become competitive (Bresser-Pereira, Oreiro, and Marconi, 2016). The maintenance of the five macroeconomic prices at their correct levels is therefore an essential component of new developmentalism theory, as Marconi and Brancher (2017: 4) explain:

The level of the exchange rate must guarantee the access of entrepreneurs to internal and external aggregate demand; the rate of interest should provide a financing or opportunity cost for investment that is below its profitability; the rate of wages should increase at the same rate as labor productivity (the variation may be higher only when capital productivity is increasing); the rate of inflation must be low enough to avoid a significant reduction in the purchasing power of society[...] [...] and all these prices, once set at the right level, end up guaranteeing a sufficient profit rate on average (in aggregate) to stimulate the amount of investment necessary for the growth process, and which varies according to the stage of the development process of each society.

Thus, according to new developmentalism theory, the growth policy of external indebtedness (external savings) for developing countries which already run deficits presents more of an obstacle than an advantage (Bresser-Pereira, 2016). This theoretical approach explains that growth depends on investment, interest rates, expected profit and demand, and that all of these components are rarely guaranteed by an overvalued currency, especially in the long term. As long-term overvaluation becomes more "rule than exception" in developing countries, an exchange rate policy does not easily neutralize the long-term exchange rate. As already explained in Bresser-Pereira and Gala (2008), when financing is done in foreign currency, usually in a strong and appreciated currency, the rate of substitution of domestic for foreign savings increases, associated with a current account deficit. If the current account deficit is widened by new loans, the exchange rate will appreciate further and, as a result, the disconnect will be stronger, and more and more companies will lose their market to foreign businesses. In relation to revenues, the more appreciated the currency, the greater the purchasing power of consumers, and, consequently, the country's domestic savings will drop, replaced by external savings. In any case, capital inflows appreciate the exchange rate and discourage investment.

As an example, Bresser-Pereira (2017a) presents the successful experience of East Asian countries, including Japan, which did not open their markets to foreign investment. Although Japan does not have the natural resources to export commodities, the preexisting traditional system had developed an education system and an internal market that helped create a short-lived import-substitution model, quickly followed by exports of manufactured goods.

The conclusion of Bresser-Pereira (2017a), based on new developmentalism 
theory, shows a way out in which developing countries do not need foreign financing in the usual way that it is carried out today - in strong foreign currencies. It is important to make it clear that the theory is not against foreign currency financing for large investment projects; however, it opposes the use of such funding to finance current account deficits. As the author himself declares, if the practice continues, developed countries will continue to occupy the domestic market of developing countries with high interest loans and the entry of multinationals in exchange for short term consumption.

\section{THE CHALLENGE: LOCAL CURRENCY FINANCING}

After laying out the problems of indebtedness with foreign capital and demonstrating, through new developmentalism theory, that developing countries should not be financed with foreign currencies, the challenge remains: how to stimulate investment in developing countries knowing that they will need infrastructure resources - including roads, energy and water supply, and social projects? How to minimize exchange rate risks to attract capital?

As there is significant demand for financial solutions in domestic currency by local governments and public sector companies, one option would be to develop the internal long-term credit market, based on domestic capital markets and national and regional development banks (Hoschka, 2005). However, as pointed out in the Asian Development Bank (ADB) report, in most developing countries, domestic capital markets are not sufficiently developed to provide long-term local currency loans (Bestani and Sagar, 2004). Perry (2009) points out three reasons for this. First, foreign exchange swap markets are very sensitive to credit risk, and only countries with relatively low risk have been able to develop these markets. Second, changes in tax regulations and market infrastructure are necessary for local markets to develop. Third and last, these markets have developed only in countries that have achieved stability, combined with consistently low inflation, flexible exchange rate regimes and credibility of central bank policies. And despite domestic capital market development being an essential step, this does not disqualify long-term financing by foreign financiers.

For Hoschka (2005), MDBs play a potentially important role in reducing exchange mismatch, helping to develop the domestic financial sector and catalyzing the mobilization of financial resources in local currency. According to Wang (2017), MDBs should recognize that the real cost of direct foreign currency lending is roughly the same as local currency lending, with the advantage of minimizing currency risk and bringing the "seal of approval" effect, which can convince other international funders to participate. Hoschka (2005) adds that, by issuing local currency bonds, MDBs also play an important role in paving the way for a better functioning of local capital markets - setting standards in documentation and execution, defining best practices and introducing innovations in available financial instruments. In this sense, getting MDBs and developing countries to work together in a search 
for financial solutions in local currency would generate the perception that MDBs would be "leading by example" (Hoschka, 2005) - a very different brand from that which made MDBs responsible for the indebtedness of several countries, including Brazil in the 1990s.

According to Perry (2009), another benefit of issuing bonds in local currency would be to contribute to a greater internationalization of different countries' local currencies, attracting foreign investors and allowing local issuers to raise foreign capital in local currency rather than in foreign currency. Thus, MDBs can help to progressively reduce the need for loans in foreign currencies and thus contribute to reducing currency mismatches that, as argued, can have serious macroeconomic implications.

Bestani and Sagar (2004) comment on the role of the MDBs in helping to develop local capital markets in general, providing support to the government through comprehensive financial, monetary and fiscal regulatory policies to strengthen financial government institutions such as national and regional development banks. For the authors, such support, combined with more accurate market information, credit and guarantee reporting systems, helps create a more robust financial system, more likely to provide the long-term financing needed for infrastructure projects.

NDB and AIIB are examples of new multilateral institutions that are acting to reduce the dependence of developing countries on foreign currency financing, principally the US dollar (Wang, 2017). Although both banks have used the US dollar in their initial capitalization and their first loans, according to Wang (2017), they plan to increase the use of local currencies over time. For example, in July 2016 NDB issued \$ 448.37 million in bonds in the official currency of China, the Renminbi (RMB), to finance sustainable investment projects in the country - following also the global agenda of the Sustainable Development Goals (ODS).

Even though we can recognize that the new multilateral institutions are taking significant steps to support local markets, progress is uneven, and most traditional multilateral financing is still being made in foreign currency, especially in dollars. According to Perry (2009), MDBs, especially the World Bank, could play a much more ambitious role in providing local currency loans and helping to develop domestic markets in underdeveloped countries. Eichengreen, Hausmann and Panizza (2003) show that local currency bonds could be attractive investment alternatives with diversified risk and high rates of return for international investors. They suggest that, once the World Bank was willing to play a more active role in the markets of developing countries, it could take on the initial costs of creating local currency bonds and of market development so that other international funders may become interested in issuing debt tied to these indices.

However, according to Perry (2009), while domestic capital market development is a priority for most developing countries, the ability to implement the necessary changes is limited by the size, depth and efficiency of each national market. For example, Hoschka (2005) mentions the need to create an adequate regulatory environment and the strategic role of the government in ensuring the success of 
local currency products, based on effective management of assets and liabilities. From the MDBs' point of view, Hoschka (2005) argues, local currency financing still raises a number of issues related to treasury management and risk. That is, the road to efficient long-term domestic capital markets is likely to be long.

\section{CONCLUSION}

The objective of this paper was to discuss a key component that may provide greater flexibility to meet demand for investment in developing countries, namely, the ability of MDBs to provide loans in local rather than foreign currency. To this end, we have laid out here a starting point - through a review of the origin and recent evolution of MDBs, the identification of a compelling problem and a compelling policy solution, namely that of foreign currency financing and the way out based on new developmentalism theory, and a challenge: increasing local currency financing by multilateral institutions.

We note that, despite the continual reassessment over the years of the mission of MDBs in financing development at the regional or global scale, foreign currency financing nonetheless remains the standard practice. We suggest a departure from neoliberal ideological radicalism to develop a shared vision of essential financial changes and innovations in MDBs. In addition, a more critical debate on the rationale and effectiveness of MDBs' financial operations towards the public sector in developing countries seems indispensable, as more traditional banks perceive and adapt to the new wave of transformations.

This turns on accepting the importance of a central problem, understood here as the consequences of foreign currency financing, that is, the deleterious foreign currency mismatches and weight of foreign debt experienced by many developing countries, including Brazil. Despite these economies being constantly subject to volatile conditions and currency devaluation, it is nonetheless precisely the developing countries themselves that take on the cost of currency risks involved - the more the exchange rate is overvalued, the larger the current account deficit. This creates one of the most important and problematic issues of international financing: the inability of MDBs to provide a steady and reliable flow of investment capital to developing countries.

The way out of this problem can be found in new developmentalism theory (Bresser-Pereira, 2006, 2016). Bresser-Pereira both draws attention to the importance of long-term macroeconomic price equilibrium and reiterates the high risk of growth with external savings in developing countries. As developing countries usually have overvalued exchange rates not easily neutralized in the long-term, a shift from domestic savings to foreign savings often occurs, accompanied by a current account deficit. The author is not against foreign financing of investment under certain conditions, but rather against foreign financing that will, because of these realities in developing countries, replace domestic savings by external savings and thus produce current account deficits, in a vicious cycle. 
Finally, the challenge remains of developing alternatives to meet the demand for investment in social and infrastructure projects in developing countries, as domestic capital is still insufficient in the face of these needs. We argue that one of the best options that emerges from this brief article is local currency financing by MDBs. It is evident that, increasingly, mobilizing development finance also means developing and exploiting long-term local currency financial markets, such as the issuance of bonds, the provision of financing and guarantees in national currencies for the public sector, moving away from the risk of foreign currency indebtedness and the attendant currency problems. In addition, multilateral organizations play an important role in assisting the necessary tax and regulatory reforms necessary for the development of markets for local financing.

Promising local currency funding initiatives exist, such as those recently promoted by the NDB and AIIB. However, such practices remain far from their full potential. The strong demand and powerful rationale for local currency financing solutions from MDBs should lead these institutions to abandon traditional approaches based on foreign currency lending and move instead towards policies able to capitalize on the new theories and policy prescriptions of new developmentalism theory. To bridge the gap between the current MDB practices and fully realize their possible contributions to regional and global development, it will also be necessary to reconsider other problems with current policies, reassess risk assessment, analysis, and management, provide technical assistance to policymakers in developing countries and, finally, overcome biases against new forms of financing.

\section{REFERENCES}

Bestani, Robert e Sagar, Ajay (2004) “The Local Currency Financing Revolution”, Asian Development Bank, Mandaluyong.

Bresser-Pereira, Luiz Carlos (1995) “A Teoria do Desenvolvimento Econômico e a Crise de Identidade do Banco Mundial”, Revista de Economia Política, 15(57): 5-40.

Bresser-Pereira, Luiz Carlos (2006) "O Novo Desenvolvimentismo e a ortodoxia convencional”, São Paulo em Perspectiva, 20(3): 5-24.C

Bresser-Pereira, Luiz Carlos (2007) Macroeconomia da Estagnação, São Paulo: Editora 34.

Bresser-Pereira, Luiz Carlos (2016). "Reflecting on new and classical developmentalism", Review of Keynesian Economics, 4 (3): 331-352.

Bresser-Pereira, Luiz Carlos (2017a) "Why the Rest doesn't need foreign finance", in Vladimir Popov and Piotr Dutkiewicz, orgs. Mapping a New World Order: The Rest Beyond the West, London: Edward Elgar: 71-90.

Bresser-Pereira, Luiz Carlos (2017b) “Desenvolvimento, sofisticação produtiva, valor-trabalho e salários”, FGV, São Paulo, Texto para discussão 450.

Bresser-Pereira, Luiz Carlos (2018) "Why multilateral development banks should provide finance in domestic currencies: a growth and financial stability proposal”, paper presented in the Shanghai Forum, Fudan University, May 26-28, 2018 available in: http:/www.bresserpereira.org.br/ papers/2018/298-Multilateral-dev-banks-Shanghai-Forum.pdf.

Bresser-Pereira, Luiz Carlos e Nakano, Yoshiaki (2003) "Economic growth cum foreign savings?” Brazilian Journal of Political Economy, 22(2): 3-27. 
Bresser-Pereira, Luiz Carlos e Gala, Paulo (2008) "Foreign savings, insufficiency of demand, and low growth", Journal of Post Keynesian Economics, 30 (3): 315-334.

Bresser-Pereira, Luiz Carlos, José Luis Oreiro e Nelson Marconi (2016) Macroeconomia Desenvolvimentista, Rio de Janeiro: Elsevier.

Birdsall, Nancy e Londono, Juan Luis (1997) "Asset inequality matters: an assessment of the World Bank's approach to poverty reduction", American Economic Review, 87: 32-37.

Frieden, Jeffry (2014) Currency politics: The political economy of exchange rate policy, Princeton: Princeton University Press.

Eichengreen, Barry, Hausmann, Ricardo e Panizza, Ugo (2003) "Original Sin: The Pain, the Mystery and the Road to Redemption", Inter-American Development Bank, Washington, DC.

Hoschka, Tobias C. (2005) "Local Currency Financing-The Next Frontier for MTBs”, Asian Development Bank, Mandaluyong, Working Paper 078.

Marconi, Nelson e Brancher, Marco (2017) “A política econômica do novo desenvolvimentismo”, Economia Contemporânea, Número Especial: 1-31.

Perry, Guillermo (2009) "Beyond Lending: How Multilateral Banks Can Help Developing Countries Manage Volatility”, Washington, DC: Center for Global Development.

Prebisch, Raúl (1962). “The economic development of Latin America and its principal problems”, Economic Bulletin for Latin America, 7(1).

Reinert, Erik S. (2007) Como os Países Ricos Ficaram Ricos [...] e Por Que os Países Pobres Continuam Pobres, Rio de Janeiro: Editora Contraponto.

Roberts, Cynthia, Leslie Elliot Armijo and Saori Katada (2017) The BRICS and Collective Financial Statecraft, Oxford: Oxford University Press.

Shelepov, Andrey (2017) "New and Traditional Multilateral Development Banks: Current and Potential Cooperation”, International Organisations Research Journal, 12(1).

Wang, Hongying (2017) "New Multilateral Development Banks: Opportunities and Challenges for Global Governance”, Global Policy, 8 (1): 113-118. 